26. Australian Government, National Health and Medical Research Council (2011) Emergency care acute pain management manual. http://www.nhmrc. gov; Zugegriffen: 14. Sept. 2013

27. Hustey FM, Meldon SW (2002) The prevalence and documentation of impaired mental status in elderly emergency department patients. Ann Emerg Med 39:248-253

28. Keita H, Tubach F, Maalouli J et al (2008) Age-adapted morphine titration produces equivalent analgesia and adverse effects in younger and older patients. Eur J Anaesthesiol 25:352-356

29. Lacroix I, Berrebi A, Garipuy D et al (2011) Buprenorphine versus methadone in pregnant opioiddependent women: a prospective multicenter study. Eur J Clin Pharmacol 67:1053-1059

30. Lvovschi V, Aubrun F, Bonnet P et al (2008) Intravenous morphine titration to treat severe pain in the ED. Am J Emerg Med 26:676-682

31. Manterola C, Vial M, Moraga J, Astudillo P (2011) Analgesia in patients with acute abdominal pain Cochrane Database Syst Rev 1:CD005660. DOI 10.1002/14651858.CD005660.pub3

32. Marhofer P, Schrögendorfer K, Koinig H et al (1997) Ultrasonographic guidance improves sensory block and onset time of three-in-one blocks. Anesth Analg 85:854-857

33. Niederhoff H, Zahradnik HP (1983) Analgesics during pregnancy. Am J Med 75:117-120

34. Overdyk F, Carter R, Maddox R (2006) New JCAHO pain standard bigger threat to patient safety than envisioned (letter). Anesth Analg 102:1596

35. Roberts DC, McKay MP, Shaffer A (2008) Increasing rates of emergency department visits for elderly patients in the United States, 1993 to 2003. Ann Emerg Med 51:769-774

36. Rupp T, Delaney KA (2004) Inadequate analgesia in emergency medicine. Ann Emerg Med 43:494-503

37. Silka PA, Roth M, Moreno G et al (2004) Pain scores improve analgesic administration patterns for trauma patients in the emergency department. Acad Emerg Med 11:264-270

38. Stalnikowicz R, Mahamid R, Kaspi S, Brezis M (2005) Undertreatment of acute pain in the emergency department: a challenge. Int J Qual Health Care17:173-176

39. Strange GR, Chen EH (1998) Use of emergency departments by elder patients: a five-year follow-up study. Acad Emerg Med 5:1157-1162

40. Todd KH, Ducharme J, Choiniere M et al (2007) Pain in the emergency department: results of the pain and emergency medicine initiative (PEMI) multicenter study. J Pain 6:460-466

41. Von Korff M, Ormel J, Keefe FJ, Dworkin SF (1992) Grading the severity of chronic pain. Pain 50:133149

42. Vila H Jr, Smith RA, Augustyniak MJ et al (2005) The efficacy and safety of pain management before and after implementation of hospital-wide pain management standards: is patient safety compromised by treatment based solely on numerical pain ratings? Anesth Analg 101:474-480

43. Vila Jr H, Downs JB (2006) New JCAHO pain standard bigger threat to patient safety than envisioned (letter). Anesth Analg 102:1596

44. White PF, Kehlet H (2007) Improving pain management: are we jumping from the frying pan into the fire? Anesth Analg 105:10-12

45. Wilson JE, Pendleton JM (1989) Oligoanalgesia in the emergency department. Am J Emerg Med 7:620-623
Anaesthesist 2013 · 62:902-913

DOI 10.1007/s00101-013-2230-6

Published online: 23. November 2013

(C) Springer-Verlag Berlin Heidelberg 2013

\author{
X. Liu $\cdot$ C. Wei $\cdot$ Z. Wang $\cdot$ H. Wang
}

Department of Anesthesiology, 309th Hospital of PLA, Beijing

\section{RETRACTED ARTICLE: Different anesthesia methods for laparoscopic cholecystectomy}

Dieser Beitrag wird wegen Plagiarismus zurückgezogen, da er mit einer früheren Publikation identisch ist:

Imbelloni LE, Fornasari M, Fialho JC et al (2010) General anesthesia versus spinal anesthesia for laparoscopic cholecystectomy. Rev Bras Anestesiol 60:217-227

This article has been retracted due to plagiarism because it is identical with the publication:

Imbelloni LE, Fornasari M, Fialho JC et al (2010) General anesthesia versus spinal anesthesia for laparoscopic cholecystectomy. Rev Bras Anestesiol 60:217-227

\section{Corresponding address}

Prof. Dr. R. Rossaint

Klinik für Anästhesiologie, RWTH

Pauwelsstr. 30, 52074 Aachen

Germany

rrossaint@ukaachen.de
Die Online-Version des Originalartikels können Sie unter http://dx.doi.org/10.1007/s00101-011-1863-6 finden. 